doi: $10.32505 /$ tarbawi.v8i2.2065

\title{
Systematic Literatur Review: Adversity Quotient dan Self Efficacy dalam Pembelajaran Matematika
}

\author{
Aan Putra1, Muthia Roza ${ }^{2}$ \\ 1,2Institut Agama Islam Negeri Kerinci, Indonesia \\ aanputra283@iainkerinci.ac.id
}

\begin{abstract}
Innovation in learning is needed. One of the innovations that can be done is an innovation from within students, namely adversity quotient and self-efficacy which can generate interest in learning and improve student learning outcomes. This study aims to conduct a literature review on adversity quotient and self-efficacy and their relation to mathematics learning. The research method chosen in this study is the SLR (Systematic Literature Review) method. Data collection was carried out by documenting and reviewing all articles regarding adversity quotient and selfefficacy published in the 2011-2020 period. The articles used in this study were 30 accredited national journal articles obtained from the Google Scholar database using the Publish or Perish application. Based on this research, it was found that adversity quotient and self-efficacy can improve mathematics learning, learning outcomes and learning effectiveness of students.
\end{abstract}

Keywords: Adversity Quotient, Self-Efficacy, Mathematics Learning

\begin{abstract}
Abstrak
Inovasi dalam pembelajaran sangat diperlukan. Salah satu inovasi yang dapat dilakukan adalah inovasi dari dalam diri siswa yaitu adversity quotient dan self-efficacy yang dapat menimbulkan minat belajar dan meningkatkan hasil belajar peserta didik. Penelitian ini bertujuan untuk melakukan kajian literatur tentang adversity quotient dan self-efficacy dan kaitannya dengan pembelajaran matematika. Metode penelitian yang dipilih dalam penelitian ini ialah metode SLR (Systematic Literature Review). Pengumpulan data dilakukan dengan mendokumentasi dan mereviu semua artikel mengenai adversity quotient dan self-efficacy yang diterbitkan dalam kurun waktu 2011-2020. Artikel yang digunakan pada penelitian ini sebanyak 30 artikel jurnal nasional terakreditasi yang diperoleh dari database Google Scholar menggunakan aplikasi Publish or Perish. Berdasarkan penelitian ini didapatkan bahwa adversity quotient dan selfefficacy dapat meningkatkan pembelajaran matematika, hasil belajar dan keefetifan belajar peserta didik.
\end{abstract}

Kata kunci: Adversity Quotient, Self-Efficacy, Pembelajaran Matematika 


\section{A. Pendahuluan}

Hasil studi PISA (Programme for International Student Assessment) pada 2012 mengungkapkan bahwa dalam melakukan pengerjaan soal tingkat tinggi terdapat $43,3 \%$ siswa menyerah dan $34,1 \%$ siswa lebih memilih melakukan penundaan dalam mengerjakannya (Afri, 2018). Ini mengungkapkan bahwa keyakinan diri dan ketangguhan siswa dalam menghadapi masalah cenderung rendah. Untuk memperoleh hasil belajar, siswa tidak hanya membutuhkan model pembelajaran yang tepat tetapi juga dorongan dari dalam diri siswa yang kuat yaitu adversity quotient dan selfefficacy (Saidah \& Lailatuzzahro, Al-Akhda, 2014).

Adversity quotient atau $\mathrm{AQ}$ merupakan sebuah penilaian yang digunakan untuk menilai sejauh mana seseorang menyelesaikan permasalahan yang penuh dengan tantangan menjadi sebuah peluang keberhasilan (Yanti \& Syazali, 2016). AQ menganalisa seberapa mampu individu menghadang kesukaran, bersikukuh menangkis jenis dari kesulitan hingga menemukan solusi. AQ seseorang dikelompokkan dalam 3 tipe, yaitu quitter, camper dan climber. Siswa yang tergolong pada tipe quitter merupakan siswa yang mudah menyerah dan tidak menyukai tantangan. Kelompok siswa tipe camper yaitu siswa yang memiliki kemauan tetapi tidak ingin mengambil resiko, sedangkan siswa tipe climber adalah siswa yang sulit menyerah dan berani menghadapi segala resiko (Stoltz, 2000). AQ memiliki dampak terhadap hasil belajar siswa. Semakin tinggi tingkat AQ seseorang maka semakin tinggi pula kemungkinan untuk meraih sukses, siswa yang berada pada level AQ yang tinggi ia akan mengatasi segala kesulitan walaupun keadaan lebih sulit dari sebelumnya. Sebaliknya semakin rendah tingkat AQ seseorang maka ia akan mudah menyerah, tidak ingin mengatasi segala kesulitan, dan ia akan selalu menghindar dari segala tantangan (Afri, 2018).

Tidak hanya AQ sebagai faktor pendorong peningkatan hasil belajar siswa tetapi juga self-efficacy (SE). SE merupakan keyakinan yang ada pada diri untuk melakukan penyelesaian masalah sekarang maupun akan datang 
(Bandura \& Watts, 1996) dan merupakan bagian yang sangat penting bagi seseorang untuk mencapai sebuah prestasi (Pudjiastuti, 2012). Hal ini karena SE dapat membantu seseorang menghadapi sesuatu yang sulit, ia juga termasuk tingkah laku yang ada pada diri peserta didik, kegigihan dan seberapa ingin seorang siswa menghadapi segala masalah dan hambatanhambatan yang mengganggunya pada saat menyelesaikan permasalahan yang dihadapinya (Rahmi, Nadia, Hasibah, \& Hidayat, 2017).

Pembelajran matematika ialah pembelajaran yang telah tertata secara sistematis, akurat, dapat dijadikan alat untuk menghadapi permasalahan dikehidupan sehari-hari, diperlukan untuk meningkatkan daya pikir, dan memiliki keterkaitan dengan ilmu lainnya (Isfayani, Johar, \& Munzir, 2018; Wulansari, Putra, Rusliah, \& Habibi, 2019). Pembelajaran matematika sangat penting dipelajari. Namun, pembelajaran matematika ini bersifat abstrak dianggap sulit dan menakutkan. Jadi perlu usaha yang maksimal, kegigihan dan pantang menyerah. Oleh karena itu, untuk mencapai hasil belajar yang optimal, AQ dan SE sangat dibutuhkan (Hidayat, 2017).

Hasil penelitian menunjukkan bahwa beberapa model pembelajaran memberi pengaruh positif pada pembelajaran matematika (Zakiyah, Imania, Rahayu, \& Hidayat, 2018; Wulansari, Putra, Rusliah, \& Habibi, 2019). Namun penelitian yang ada mengabaikan kemauan siswa yang muncul dari dalam dirinya untuk mengoptimalkan pembelajaran matematika. Oleh karena itu, peneliti memandang perlu mereviu berbagai artikel terkait adversity quotient dan self-efficacy dan kaitannya dengan pembelajaran matematika. Hasil penelitian ini diharapkan dapat memberi pijakan yang kokoh bagi peneliti untuk mempertimbangkan AQ dan SE siswa mencapai hasil belajar yang optimal. 


\section{B. Metode}

Metode yang digunakan dalam penelitian ini adalah metode SLR (Systematic Literature Review). SLR ini peneliti lakukan dengan mengidentifikasi, mengkaji, mengevaluasi serta menafsirkan semua penelitian yang tersedia. Dengan metode ini peneliti melakukan reviu dan mengidentifikasi jurnal-jurnal secara sistematis yang pada setiap prosesnya mengikuti langkah-langkah yang telah ditetapkan (Triandini, Jayanatha, Indrawan, Werla Putra, \& Iswara, 2019). Untuk merampungkan penelitian ini, peneliti mengumpulkan artikel jurnal pada database Google Scholar dengan bantuan aplikasi Publish or Perish. Kata kunci adalah adversity quotient, selfefficacy, pembelajaran matematika dan gabungannya. Artikel yang dikumpulkan hanya artikel yang dipublikasikan dalam rentang waktu 2016 hingga 2020. Dari berbagai artikel, peneliti memilih 20 artikel yang terkalit erat dengan kata kunci yang digunakan.

Langkah selanjutnya, peneliti mengelompokkan artikel-artikel menjadi dua yaitu artikel yang adversity quotient dan artikel yang terkait self-efficacy, baik yang berhubungan dengan pembelajaran matematika maupun hasil belajar secara umum. Metadata artikel-artikel tersebut ditabulasi dalam tabel yang meliputi nama penulis, judul, tahun terbit, nama jurnal, jenis penelitian dan hasil penelitian. Setelah itu, peneliti mereviu dan menganalisis artikel tersebut secara mendalam terutama mengenai hasil penelitian yang tersaji pada bagian pembahasan dan bagian kesimpulan. Pada bagian akhir penelitian, peneliti membandingkan temuan yang tersaji dalam artikel dan memberi kesimpulan. 


\section{Hasil dan Pembahasan}

\section{Hasil}

Tabulasi data artikel yang didokumentasi terkaik adversity quotient sebanyak 10 artikel disajikan pada Tabel 1.

Tabel 1 Penelitian terkait adversity quotient

\begin{tabular}{|c|c|c|}
\hline Peneliti dan Tahun & Jurnal & Hasil Penelitian \\
\hline $\begin{array}{l}\text { (Handaru, Parimita, \& } \\
\text { Mufdhalifah, 2015) }\end{array}$ & $\begin{array}{l}\text { Jurnal Manajemen } \\
\text { dan } \\
\text { Kewirausahaan }\end{array}$ & $\begin{array}{l}\text { Penelitian } \\
\text { penelitian deskriptif dengan } \\
\text { kesimpulan AQ dan SE } \\
\text { memberi pengaruh yang } \\
\text { positif terhadap } \\
\text { kewirausahaan mahasiswa. }\end{array}$ \\
\hline $\begin{array}{l}\text { (Rosita \& Rochmad, } \\
\text { 2016) }\end{array}$ & $\begin{array}{l}\text { Journal of } \\
\text { Mathematics } \\
\text { Education } \\
\text { Research }\end{array}$ & $\begin{array}{l}\text { Penelitian ini adalah } \\
\text { penelitian kombinasi tipe } \\
\text { concurrent embedded dengan } \\
\text { kesimpulan siswa dengan } \\
\text { Adversity Quotient (AQ) baik } \\
\text { lebih mampu menyelesaikan } \\
\text { pemecahan masalah sesuai } \\
\text { Newman Procedure. }\end{array}$ \\
\hline $\begin{array}{l}\text { (Bariyyah Hidayati, } \\
\text { 2016) }\end{array}$ & Persona & $\begin{array}{lcr}\text { Penelitian } & \text { ini } & \text { adalah } \\
\text { penelitian korelasi dengan } & \text { dep } \\
\text { kesimpulan } & \text { konsep diri, } \\
\text { adversity quotient dan } \\
\text { penyesuaian diri pada remaja } \\
\text { berada di tingkat yang sama. }\end{array}$ \\
\hline (Mena, 2016) & Kreano & $\begin{array}{l}\text { Penelitian ini adalah } \\
\text { penelitian deskriptif kualitatif } \\
\text { yang menyimpulkan bahwa } \\
\text { siswa tipe climber dapat } \\
\text { menyelesaikan masalah } \\
\text { kontekstual dengan baik. }\end{array}$ \\
\hline $\begin{array}{l}\text { (Latifah \& Astri, } \\
\text { 2017) }\end{array}$ & $\begin{array}{l}\text { Economic } \\
\text { Education } \\
\text { Analysis Journal }\end{array}$ & $\begin{array}{l}\text { Penelitian ini } \\
\text { penelitian kuantitatif } \\
\text { kesimpulan dengan } \\
\text { kepribadian secara tidak } \\
\text { langsung memengaruhi self- } \\
\text { efficacy wirausaha. }\end{array}$ \\
\hline $\begin{array}{l}\text { (Naila Khusna, } \\
\text { Nugraha Arif } \\
\text { Karyanta, 2017) } \\
\end{array}$ & Wacana & $\begin{array}{l}\text { Ini adalah penelitian korelasi } \\
\text { dengan kesimpulan dukungan } \\
\text { keluarga memiliki hubungan }\end{array}$ \\
\hline
\end{tabular}




\begin{tabular}{|c|c|c|}
\hline & & $\begin{array}{l}\text { yang signifikan terhadap } \mathrm{AQ} \\
\text { yang dimiliki siswa. }\end{array}$ \\
\hline (Hanifa, 2017) & Psikoborneo & $\begin{array}{lr}\text { Ini adalah } & \text { penelitian } \\
\text { kuantitatif } & \text { yang } \\
\text { berkesimpulan } & \text { bahwa } \\
\text { semakin baik EQ dan AQ maka } \\
\text { semakin rendah kecemasan } \\
\text { menghadapi dunia kerja. }\end{array}$ \\
\hline (Ismawati \& & Journal of & Ini adalah penelitian \\
\hline Hindarto, 2017) & $\begin{array}{l}\text { Mathematics } \\
\text { Education } \\
\text { Research }\end{array}$ & $\begin{array}{l}\text { kombinasi kuantitatif dan } \\
\text { kualitatif dengan desain } \\
\text { concurrent embedded dengan } \\
\text { kesimpulan bahwasanya } \\
\text { pembelajaran PBL dengan } \\
\text { strategi scaffolding terbukti } \\
\text { efektif, siswa dengan AQ } \\
\text { Climber dapat menyelesaikan } \\
\text { pemecahan masalah dengan } \\
\text { baik. }\end{array}$ \\
\hline (Hidayat, 2017) & Kalamatika & $\begin{array}{lr}\text { Penelitian ini } & \text { adalah } \\
\text { penelitian eksperimen dengan } & \text { bahwa } \\
\text { kesimpulan } & \text { pembelajaran } \\
\text { Driven Inquiry yang diperoleh } \\
\text { siswa lebih baik daripada } \\
\text { pembelajaran langsung. }\end{array}$ \\
\hline $\begin{array}{l}\text { (Huda \& Mulyana, } \\
\text { 2018) }\end{array}$ & Psympathic & $\begin{array}{l}\text { Penelitian ini adalah } \\
\text { penelitian korelasi dengan } \\
\text { kesimpulan AQ berpengaruh } \\
\text { signifikan terhadap prestasi } \\
\text { akademik mahasiswa. }\end{array}$ \\
\hline $\begin{array}{l}\text { (Irfan, Juniati, \& } \\
\text { Lukito, 2018) }\end{array}$ & Apotema & $\begin{array}{l}\text { Penelitian ini adalah } \\
\text { penelitian kualitatif yang } \\
\text { berkesimpulan bahwasa } \\
\text { siswa yang memiliki AQ yang } \\
\text { bagus dapat memecahkan } \\
\text { masalah. Berbanding terbalik } \\
\text { terhadap siswa yang memiliki } \\
\text { AQ yang rendah. }\end{array}$ \\
\hline $\begin{array}{l}\text { (Hardianto \& } \\
\text { Sucihayati, 2019) }\end{array}$ & $\begin{array}{l}\text { Jurnal } \\
\text { Psibernetika }\end{array}$ & $\begin{array}{lcr}\text { Penelitian } & \text { ini } & \text { adalah } \\
\text { penelitian } & \text { korelasi } & \text { dengan } \\
\text { kesimpulan } & \text { AQ } & \text { memiliki } \\
\text { hubungan } & \text { positif } & \text { dan } \\
\text { signifikan } & \text { dengan } & \text { career } \\
\text { adaptability. } & & \\
\text { adala }\end{array}$ \\
\hline
\end{tabular}




\begin{tabular}{|c|c|c|}
\hline (Purwasih, 2019) & Aksioma & $\begin{array}{l}\text { Ini adalah penelitian } \\
\text { deskriptif kualitatif dengan } \\
\text { kesimpulan bahwa siswa } \\
\text { dengan AQ climber memiliki } \\
\text { kemampuan berpikir kreatif } \\
\text { kategori tinggi. }\end{array}$ \\
\hline $\begin{array}{l}\text { (Jana \& } \\
\text { Nugrahayuningtyas, } \\
\text { 2019) }\end{array}$ & $\begin{array}{l}\text { Jurnal Didaktik } \\
\text { Matematika }\end{array}$ & $\begin{array}{l}\text { Penelitian ini ialah penelitian } \\
\text { eksperimen diperoleh } \\
\text { kesimpulan model IMPROVE } \\
\text { efektif digunakan untuk AQ } \\
\text { yang baik. }\end{array}$ \\
\hline $\begin{array}{l}\text { (Atrizka, Sanjaya, } \\
\text { Vanthera, Limbong, \& } \\
\text { Yusfasari, 2020) }\end{array}$ & Psyche & $\begin{array}{ll}\text { Penelitian ini } & \text { adalah } \\
\text { penelitian kuantitatif } & \text { dengan } \\
\text { kesimpulan } & \text { adanya } \\
\text { perbedaan antara } \mathrm{AQ}, \mathrm{SE} \text {, dan } \\
\text { CS. }\end{array}$ \\
\hline
\end{tabular}

Dan tabulasi data artikel yang didokumentasi terkaik self-efficacy sebanyak 10 artikel disajikan pada Tabel 2.

Tabel 2 Penelitian terkait self-efficacy

\begin{tabular}{|c|c|c|}
\hline Peneliti dan Tahun & Jurnal & Hasil Penelitian \\
\hline $\begin{array}{l}\text { (Ardyanti \& Harini, } \\
\text { 2015) }\end{array}$ & $\begin{array}{l}\text { Union: Jurnal } \\
\text { Pendidikan } \\
\text { Matematika }\end{array}$ & $\begin{array}{l}\text { Penelitian ini adalah } \\
\text { penelitian ex-post facto } \\
\text { dengan kesimpulan terdapat } \\
\text { hubungan yang positif dari } \\
\text { AQ, SE, dan kebiasaan belajar } \\
\text { siswa. }\end{array}$ \\
\hline (Fitri, 2017) & $\begin{array}{l}\text { Jurnal Review } \\
\text { Pembelajaran } \\
\text { Matematika }\end{array}$ & $\begin{array}{l}\text { Penelitian ini adalah } \\
\text { penelitian quasi eksperimen } \\
\text { dengan kesimpulan bahwa } \\
\text { siswa yang belajar } \\
\text { menggunakan pendekatan } \\
\text { ATI memperoleh skor self } \\
\text { efficacy lebih baik daripada } \\
\text { pendekatan konvensional. }\end{array}$ \\
\hline (Sunaryo, 2017) & Teorema & $\begin{array}{l}\text { Penelitian ini adalah } \\
\text { penelitian deskriptif dengan } \\
\text { kesimpulan SE berada di level } \\
\text { sedang dan positif terhadap } \\
\text { pembelajaran matematika. }\end{array}$ \\
\hline
\end{tabular}




\begin{tabular}{|c|c|c|}
\hline (Yuliyani, 2017) & Jurnal Formatif & $\begin{array}{lrr}\text { Penelitian } & \text { ini } & \text { adalah } \\
\text { penelitian } & \text { survey dengan } \\
\text { kesimpulan } & \text { bahwa SE dan } \\
\text { kemampuan } & \text { berpikir positif } \\
\text { memberi } & \text { pengaruh yg } \\
\text { signifikan } & \text { terhadap } \\
\text { kemampuan } & \text { pemecahan } \\
\text { masalah. } & \end{array}$ \\
\hline $\begin{array}{l}\text { (Siregar \& Nizma, } \\
\text { 2017) }\end{array}$ & $\begin{array}{l}\text { Procedia - Social } \\
\text { and Behavioral } \\
\text { Sciences }\end{array}$ & $\begin{array}{l}\text { Ini adalah penelitian } \\
\text { deskriptif kuantitatif dengan } \\
\text { kesimpulan bahwa variabel } \\
\text { yang dominan } \\
\text { mempengaruhi minat } \\
\text { kewirausahaan siswa. }\end{array}$ \\
\hline $\begin{array}{l}\text { (Damri, Engkizar, \& } \\
\text { Anwar, 2017) }\end{array}$ & $\begin{array}{l}\text { Jurnal Edukasi: } \\
\text { Jurnal Bimbingan } \\
\text { Konseling }\end{array}$ & $\begin{array}{l}\text { Penelitian ini adalah } \\
\text { penelitian kuantitatif dengan } \\
\text { kesimpulan bahwa SE yang } \\
\text { tinggi tidak akan bermanfaat } \\
\text { jika tidak diimplementasi } \\
\text { pada tingkah laku akademik. }\end{array}$ \\
\hline $\begin{array}{l}\text { (Wasida \& Hartono, } \\
\text { 2018) }\end{array}$ & $\begin{array}{ll}\text { Jurnal } & \text { Riset } \\
\text { Pendidikan } & \\
\text { Matematika } & \end{array}$ & $\begin{array}{l}\text { Ini adalah penelitian survey } \\
\text { diperoleh kesimpulan bahwa } \\
\text { siswa sulit melakukan } \\
\text { penyelesaian soal ujian } \\
\text { nasional matematika. }\end{array}$ \\
\hline $\begin{array}{l}\text { (Masri, Suyono, \& } \\
\text { Deniyanti, 2018) }\end{array}$ & JPPM & $\begin{array}{l}\text { Penelitian } \text { ini adalah } \\
\text { penelitian Quasi-eksperimen } \\
\text { dengan kesimpulan bahwa } \\
\text { metode } \\
\text { berbasis masalah dapat } \\
\text { meningkatkan nilai siswa. }\end{array}$ \\
\hline $\begin{array}{l}\text { (Putra, Putri, Lathifah, } \\
\text { \& Mustika, 2018) }\end{array}$ & JNPM & $\begin{array}{l}\text { Ini adalah penelitian } \\
\text { deskriptif kuantitatif dengan } \\
\text { kesimpulan cara siswa } \\
\text { menjawab soal dipengaruhi } \\
\text { oleh self-efficacy nya. }\end{array}$ \\
\hline $\begin{array}{l}\text { (Isfayani, Johar, \& } \\
\text { Munzir, 2018) }\end{array}$ & Jurnal Elemen & \begin{tabular}{lr} 
Ini adalah & \multicolumn{2}{r}{ penelitian } \\
Pendekatan & kuantitatif \\
dengan kesimpulan & bahwa \\
menggunakan & model \\
pembelajaran lebih & baik \\
untuk meningkatkan & Self- \\
Efficacy.
\end{tabular} \\
\hline (ambarwati, 2018) & FPPSI & $\begin{array}{llr}\begin{array}{l}\text { Penelitian } \\
\text { penelitian }\end{array} & \text { ini } & \begin{array}{r}\text { adalah } \\
\text { deskriptif }\end{array} \\
\end{array}$ \\
\hline
\end{tabular}




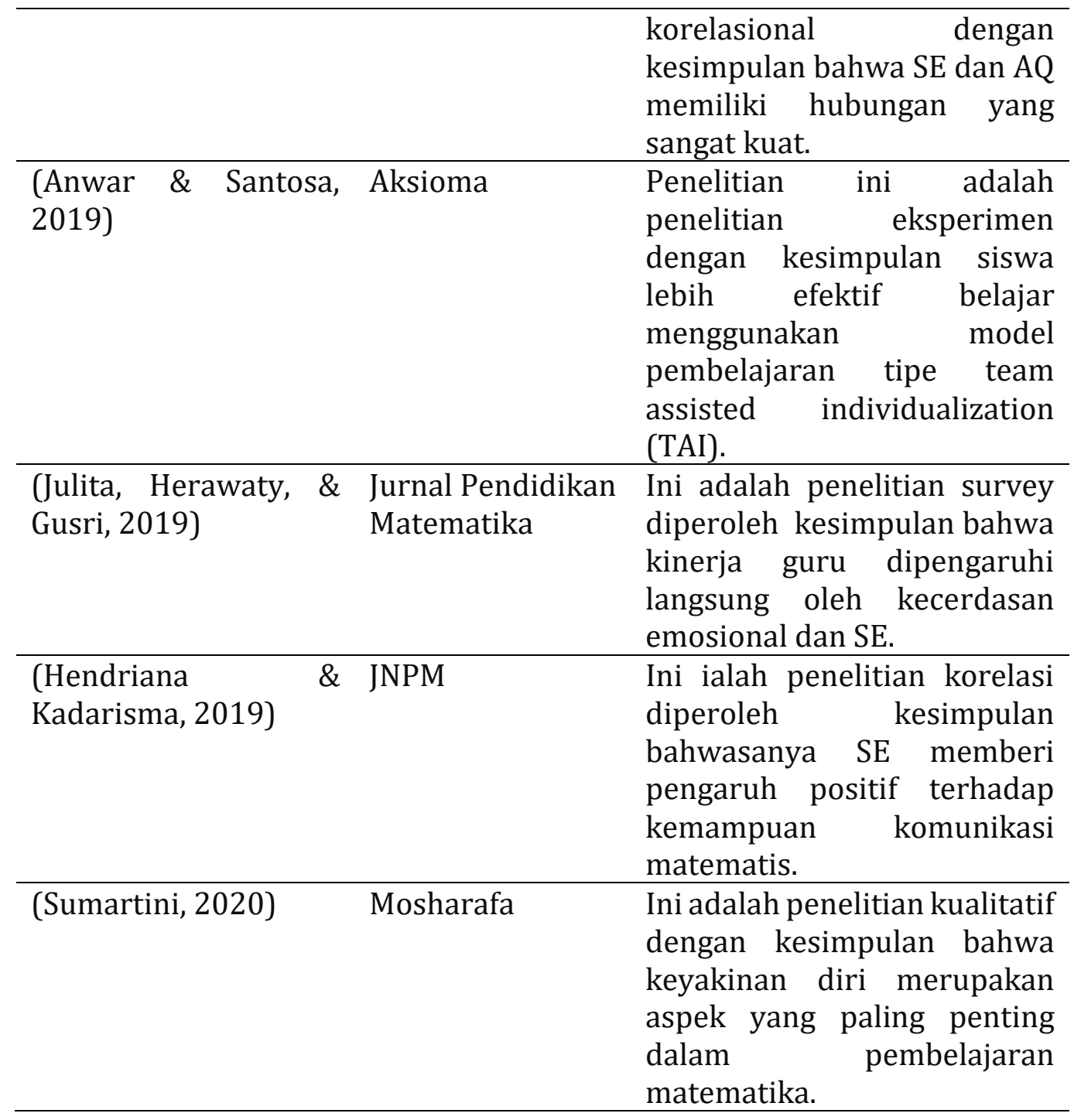

\section{Pembahasan}

\section{a. Adversity Quotient}

Berdasarkan tingkat ketangguhannya dalam menghadapi kesulitan, adversity quotient siswa digolongkan menjadi 3 yaitu quitter, camper dan climber. Tipe quitter memiliki kecenderungan menolak tantangan atau permasalahan yang ada, tipe camper ialah seorang anak yang tidak ingin mengambil resiko dan ia merasa puas terhadap apa yang telah dicapai nya pada saat ini, tipe climber adalah anak yang bisa diandalkan untuk mewujudkan perubahan, anak yang mempunyai tujuan dan pandangan kedepan (Stoltz, 2000). 
Berdasarkan hasil penelitian sebelumnya, adversity quotient memberi pengaruh signifikan terhadap pencapaian prestasi akademik (Huda \& Mulyana, 2018). Selain itu, siswa dengan AQ climber memiliki kemampuan berpikir tingkat tinggi yang baik seperti kemampuan pemecahan masalah (Mena, 2016; Rosita \& Rochmad, 2016) dan kemampuan berpikir kreatif (Hidayat, 2017; Purwasih, 2019). Hal ini karena siswa dengan AQ yang baik memiliki semangat juang yang tangguh. Semakin baik AQ siswa, maka semakin baik kemampuannya dalam memecahkan masalah (Irfan, Juniati, \& Lukito, 2018).

Dalam pembelajaran, keberhasilan penerapan metode, model dan strategi yang tepat juga perlu memperhatikan AQ siswa karena tidak terlepas dari kegigihan siswa dalam belajar mengikuti pembelajaran terutama pada materi, kegiatan dan tugas yang relatif sulit. Beberapa penelitian mengungkapkan bahwa tidak semua metode, model dan strategi belajar yang digunakan sesuai untuk semua siswa namun relatif cocok bagi siswa tipe climber (Ismawati \& Hindarto, 2017). Hal ini karena siswa tipe climber adalah siswa yang sulit menyerah dan berani menghadapi segala resiko(Stoltz, 2000), sehingga mampu menyesuaikan diri dengan berbagai suasana belajar yang dialami. Penyesuaian diri dibutuhkan ketika menghadapi sesuatu yang baru termasuk masalah dan kesulitan yang dihadapi.

Adversity quotient dibutuhkan tidak hanya dalam mencapai prestasi belajar yang optimal tetapi juga memberi pengaruh positif terhadap penyesuaian diri (Bariyyah Hidayati, 2016), pengendalian kecemasan (Hanifa, 2017), career adaptability (Hardianto \& Sucihayati, 2019). Ini menujukkan bahwa AQ juga memberi pengaruh jangka panjang bahkan untuk menghadapi dunia kerja atau lingkungan masyarakat yang ditempati siswa.

Penelitian tentang AQ dilakukan pada semua jenjang pendidikan dari tingkat sekolah dasar (Irfan, Juniati, \& Lukito, 2018), sekolah menengah (Mena, 2016; Bariyyah Hidayati, 2016; Hidayat, 2017; Purwasih, 2019), sekolah kejuruan (Hanifa, 2017) hingga perguruan tinggi (Huda \& Mulyana, 
2018; Hardianto \& Sucihayati, 2019). Hal ini mengindikasikan AQ dibutuhkan bagi semua jenjang pendidikan namun penelitian yang fokus pada pembelajaran matematika masih terbatas. Padahal pembelajaran matematika dipandang sebagai materi yang sulit dan membutuhkan usaha yang lebih gigih. Adapun hal yang perlu diperhatikan untuk meningkatkan AQ siswa ialah a) Control (Pengendalian), b) Origin and Ownership (Asal usul dan Pengakuan), c) Reach (Jangkauan), dan d) Endurance (Daya tahan) (Stoltz, 2000).

\section{b. Self-Efficacy}

Self-Efficacy merupakan bagian yang sangat penting bagi seseorang untuk mencapai sebuah prestasi (Pudjiastuti, 2012). SE dikatakan sebagai bagian penting karena ia mempengaruhi bagaimana seseorang berpikir, memotivasi diri sendiri, dan bagaimana seseorang bertindak. Maka dapat dikatakan bahwa SE memiliki peran yang sangat penting dalam menentukan sukses maupun gagalnya seseorang (Bandura \& Watts, 1996).

Berdasarkan hasil penelitian sebelumnya, self-efficacy memberi pengaruh positif terhadap kinerja guru matematika (Julita, Herawaty, \& Gusri, 2019). Selain itu, SE mempengaruhi komunikasi matematis siswa (Hendriana \& Kadarisma, 2019) dan memberi pengaruh yg signifikan antara efikasi diri (sel-efficacy) dan kemampuan berpikir positif terhadap kemampuan pemecahan masalah matematika (Yuliyani, 2017). Siswa dengan SE yang baik ialah siswa yang memiliki kepercayaan diri yang bagus dan memiliki keyakinan akan keberhasilan, ia dapat menyelesaikan soal ujian nasional yang sulit (Wasida \& Hartono, 2018).

Dalam pembelajaran, keberhasilan penerapan metode, model dan strategi yang tepat juga perlu memperhatikan SE siswa karena tidak terlepas dari keyakinan siswa dalam belajar mengikuti pembelajaran terutama pada materi, kegiatan dan tugas yang relatif sulit. Beberapa penelitian mengungkapkan bahwa tidak semua metode, model dan strategi belajar yang digunakan sesuai untuk semua siswa namun relatif cocok bagi siswa yang memiliki SE yang bagus ( Fitriani, 2017; Masri, Suyono, \& Deniyanti, 2018; 
Isfayani, Johar, \& Munzir, 2018; Anwar \& Santosa, 2019 ). Hal ini karena SE siswa dalam pembelajaran matematika berada pada level sedang dan positif (Sunaryo, 2017), sehingga mampu menyesuaikan diri dengan berbagai suasana belajar yang dialami. Penyesuaian dan keyakinan diri dibutuhkan ketika menghadapi sesuatu yang baru termasuk masalah dan kesulitan yang dihadapi.

Self-Efficacy sangat dibutuhkan untuk meningkatkan pembelajaran matematika siswa (Sunaryo, 2017). SE juga memberi pengaruh terhadap kecerdasan emosional siswa (Julita, Herawaty, \& Gusri, 2019). SE sangat dibutuhkan untuk meningkatkan kemampuan koneksi matematis menggunakan tipe rotating trio exchange (RTE) (Isfayani, Johar, \& Munzir, 2018). Adapun SE telah diteliti pada semua jenjang pendidikan, salah satunya yaitu SMP ( Sunaryo, 2017; Anwar \& Santosa, 2019; Hendriana \& Kadarisma, 2019), SMA (Wasida \& Hartono, 2018), dan juga pada guru matematika (Julita, Herawaty, \& Gusri 2019).

Hal yang perlu diperhatikan untuk meningkatkan Self-Efficacy siswa ialah a) yakin akan keberhasilan dirinya, b) Mampu mengatasi masalah yang sedang dihadapi, c) Berani menghadapi tantangan, d) Menyadari kelebihan dan kekurangan diri sendiri, e) Menunjukkan kemampuan berkomunikasi dan beradaptasi, f) Memiliki pandangan terhadap pelajaran dan pembelajaran matematika, dan g) Tidak mudah menyerah(Zakiyah et al., 2018).

\section{E. Kesimpulan}

Semakin baik AQ dan SE siswa, maka semakin baik prestasi yang diperolehnya bahkan lebih siap berkiprah di dunia kerja dan lingkungan masyarakat. Oleh karena itu, AQ dan SE perlu diperhatikan oleh guru matematika karena matematika diperlukan di dunia kerja dan kehidupan masyarakat namun dipandang sebagai materi yang sulit dan menakutkan. Dalam pembelajaran matematika, guru diharapkan dapat meningkatkan AQ dan SE siswa. Bagi peneliti lain diharapkan dapat memperdalam hubungan AQ 
dan SE terhadap berbagai kemampuan matematis siswa.

\section{Daftar Pustaka}

Afri, L. D. (2018). Hubungan adversity quotient dengan kemampuan pemecahan masalah siswa SMP pada pembelajaran matematika. AXIOM Jurnal Pendidikan \& Matematika, VII(2), 47-53. https://doi.org/10.1017/CB09781107415324.004

Ambarwati, dian. (2018). Hubungan self-efficacy dan motivasi berprestasi dengan tingkat adversity quotient mahasiswa jurusan arsitektur Universitas Brawijaya Malang. Fppsi, 2(1), 1-20.

Anwar, A., \& Santosa, R. H. (2019). Efektivitas model pembelajaran tipe team assisted individualization (TAI) ditinjau dari prestasi belajar dan selfefficacy matematika siswa SMP. AKSIOMA: Jurnal Program Studi Pendidikan Matematika, 8(1), 49-57. https://doi.org/10.24127/ajpm.v8i1.1560

Ardyanti, S. I., \& Harini, E. (2015). Hubungan antara adversity quotient, selfefficacy dan kebiasaan belajar dengan prestasi belajar matematika siswa kelas X kecantikan SMKN se-kecamatan Umbulharjo. UNION: Jurnal Pendidikan Matematika, 3(1), 296-297.

Atrizka, D., Sanjaya, K., Vanthera, D., Limbong, K. S., \& Yusfasari, R. (2020). Perbedaan adversity quotient ditinjau dari coping stress dan self-efficacy. Psyche, 13(02), 263-268.

Bandura, A., \& Watts, R. E. (1996). Self-Efficacy in changing societies. Journal of Cognitive Psychotherapy. https://doi.org/10.1891/08898391.10.4.313

Bariyyah Hidayati, K., \& . M. F. (2016). Konsep diri, adversity quotient dan penyesuaian diri pada remaja. Persona:Jurnal Psikologi Indonesia, 5(02), 137-144. https://doi.org/10.30996/persona.v5i02.730

Damri, D., Engkizar, E., \& Anwar, F. (2017). Hubungan self-efficacy dan prokrastinasi akademik mahasiswa dalam menyelesaikan tugas perkuliahan. JURNAL EDUKASI: Jurnal Bimbingan Konseling, 3(1), 74. https://doi.org/10.22373/je.v3i1.1415

Fitri, I. (2017). Self-efficacy terhadap matematika melalui pendekatan aptitude treatment interaction. Jurnal Review Pembelajaran Matematika, 2(2), 167-175. https://doi.org/10.15642/jrpm.2017.2.2.167-175 
Fitriani, W. (2017). Analisis self-efficacy dan hasil belajar matematika siswa di MAN 2 Batusangkar berdasarkan gender. Agenda, 1(1), 141-158.

Handaru, A. W., Parimita, W., \& Mufdhalifah, I. W. (2015). Membangun intensi berwirausaha melalui adversity quotient, self-efficacy, dan need for achievement. Jurnal Manajemen Dan Kewirausahaan, 17(2), 155-166. https://doi.org/10.9744/jmk.17.2.155

Hanifa, Y. (2017). Hubungan antara emotional quotient dan adversity quotient dengan kecemasan menghadapi dunia kerja pada siswa SMK. Psikoborneo, 5(1), 43-55.

Hardianto, Y., \& Sucihayati, R. B. (2019). Hubungan adversity quotient dengan career adaptability pada koas angkatan 2015 Fkg "X" di Rsgm. Psibernetika, 11(2), 79-90. https://doi.org/10.30813/psibernetika.v11i2.1433

Hendriana, H., \& Kadarisma, G. (2019). Self-efficacy dan kemampuan komunikasi matematis siswa SMP. JNPM (Jurnal Nasional Pendidikan Matematika), 3(1), 153-164. https://doi.org/10.33603/jnpm.v3i1.2033

Hidayat, W. (2017). Adversity quotient dan penalaran kreatif matematis siswa SMA dalam pembelajaran argument driven inquiry pada materi turunan fungsi. KALAMATIKA Jurnal Pendidikan Matematika, 2(1), 15-28. https://doi.org/10.22236/kalamatika.vol2no1.2017pp15-28

Huda, T. N., \& Mulyana, A. (2017). Pengaruh adversity quotient terhadap prestasi akademik mahasiswa angkatan 2013 Fakultas psikologi UIN SGD Bandung. Psympathic: Jurnal Ilmiah Psikologi, 4(1), 115-132. https://doi.org/10.15575/psy.v4i1.1336

Irfan, A., Juniati, D., \& Lukito, A. (2018). Profil pemecahan masalah pecahan siswa SD berdasarkan adversity quotient. Jurnal Program Studi Pendidikan Matematika, 4(2), 5.

Isfayani, E., Johar, R., \& Munzir, S. (2018). Peningkatan kemampuan koneksi matematis dan Self-Efficacy siswa melalui model pembelajaran kooperatif tipe rotating trio exchange (RTE). Jurnal Elemen, 4(1), 80-92. https://doi.org/10.29408/jel.v4i1.473

Ismawati, A., \& Hindarto, N. (2017). Kemampuan Pemecahan Masalah Matematika dalam Problem Based Learning dengan Strategi Scaffolding Ditinjau dari Adversity Quotient. Unnes Journal of Mathematics Education Research, 6(1), 48-58. 
Jana, P., \& Nugrahayuningtyas, A. (2019). Efektivitas model pembelajaran IMPROVE ditinjau dari kemampuan adversity quotient. Jurnal Didaktik Matematika, 6(2), 112-120. https://doi.org/10.24815/jdm.v6i2.14196

Julita, S., Herawaty, D., \& Gusri, S. A. (2019). Pengaruh kecerdasan emosional dan self-efficacy terhadap kinerja guru matematika. Jupitek, 2(2014), 2014-2017.

Latifah, L., \& Astri, W. (2017). Pengaruh personal attributes, adversity quotient dengan mediasi self-efficacy terhadap minat berwirausaha. Economic Education Analysis Journal, 6(3), 737-751.

Masri, M. F., Suyono, S., \& Deniyanti, P. (2018). Pengaruh metode pembelajaran berbasis masalah terhadap self-efficacy dan kemampuan pemecahan masalah matematis ditinjau dari kemampuan awal matematika siswa SMA. Jurnal Penelitian Dan Pembelajaran Matematika, 11(1), 116-126. https://doi.org/10.30870/jppm.v11i1.2990

Mena, A. B. (2016). Literasi matematis siswa SMP dalam menyelesaikan masalah kontekstual ditinjau dari adversity quotient (AQ). Kreano, Jurnal $\begin{array}{llll}\text { Matematika } \quad \text { Kreatif-Inovatif, } & 7(2), & \text { 187-198. }\end{array}$ https://doi.org/10.15294/kreano.v7i2.6756

Naila Khusna, Nugraha Arif Karyanta, A. T. S. (2017). Hubungan antara adversity quotient dan dukungan keluarga dengan kematangan karir remaja yatim di SMA di Surakarta. Wacana, 9(1), 14-27. https://doi.org/10.13057/wacana.v9i1.101

Pudjiastuti, E. (2012). Hubungan "Self-Efficacy" dengan perilaku mencontek mahasiswa psikologi. MIMBAR, Jurnal Sosial Dan Pembangunan, XXVIII(1), 103-112. https://doi.org/10.29313/mimbar.v28i1.344

Purwasih, R. (2019). Kemampuan berpikir kreatif matematis siswa SMP dalam menyelesaikan soal pemecahan masalah ditinjau dari adversity quotient tipe climber. AKSIOMA: Jurnal Program Studi Pendidikan Matematika, 8(2), 323-332. https://doi.org/10.24127/ajpm.v8i2.2118

Putra, H. D., Putri, A., Lathifah, A. N., \& Mustika, C. Z. (2018). Kemampuan mengidentifikasi kecukupan data pada masalah matematika dan selfefficacy siswa MTS. JNPM (Jurnal Nasional Pendidikan Matematika), 2(1), 48-61. https://doi.org/10.33603/jnpm.v2i1.862

Rahmi, S., Nadia, R., Hasibah, B., \& Hidayat, W. (2017). The relation between Self-Efficacy toward math with the math communication competence. Infinity

Journal,

$6(2)$

177-182. 
https://doi.org/10.22460/infinity.v6i2.p177-182

Rosita, D., \& Rochmad. (2016). Analisis kesalahan siswa dalam pemecahan masalah ditinjau dari adversity quotient pada pembelajaran creative problem solving. Unnes Journal of Mathematics Education Research (UJMER), 5(2), 106-113. http://journal.unnes.ac.id/sju/index.php/ujmer

Saidah, S., \& Lailatuzzahro, Al-Akhda, A. (2014). Hubungan self-efficacy dan adversity quotient (AQ). Jurnal Psikologi, 2(2), 54-61.

Siregar, D. A., \& Nizma, C. (2017). Pengaruh adversity quotient, need for achievement dan self-efficacy terhadap minat berwirausaha mahasiswa jurusan akuntasi politeknik negeri Medan. Procedia - Social and Behavioral Sciences, 1(2), 737-743.

Stoltz, P. G. (2000). Adversity quotient: Mengubah hambatan menjadi peluang. In Jakarta: Gramedia Widiasarana Indonesia.

Sumartini, T. S. (2020). Self-efficacy calon guru matematika. Mosharafa: Jurnal Pendidikan Matematika, 9(3), 419-428.

Sunaryo, Y. (2017). Pengukuran self-efficacy siswa dalam pembelajaran matematika di MTSN 2 Ciamis. Teorema, 1(2), 39-44.

https://doi.org/10.25157/.v1i2.548

Triandini, E., Jayanatha, S., Indrawan, A., Werla Putra, G., \& Iswara, B. (2019). Metode systematic literature review untuk identifikasi platform dan metode pengembangan sistem informasi di Indonesia. Indonesian Journal of Information Systems, 1(2), 63-77. https://doi.org/10.24002/ijis.v1i2.1916

Wasida, M. R., \& Hartono, H. (2018). Analisis kesulitan menyelesaikan soal model ujian nasional matematika dan self-efficacy siswa SMA. Jurnal Riset Pendidikan Matematika, 5(1),82-95. https://doi.org/10.21831/jrpm.v5i1.10060

Wulansari, T., Putra, A., Rusliah, N., \& Habibi, M. (2019). Pengaruh model pembelajaran berbasis masalah pada materi statistika terhadap kemampuan penalaran statistik siswa. AKSIOMA : Jurnal Matematika Dan Pendidikan Matematika, 10(1), 35-47. https://doi.org/10.26877/aks.v10i1.3647

Yanti, A. P., \& Syazali, M. (2016). Analisis proses berpikir siswa dalam memecahkan masalah matematika berdasarkan langkah-langkah bransford dan stein ditinjau dari adversity quotient. Al-Jabar: Jurnal 
Pendidikan Matematika, 7(1), 63-74.

Yuliyani, R. (2017). Peran efikasi diri (self-efficacy) dan kemampuan berpikir positif terhadap kemampuan pemecahan masalah matematika. Jurnal Ilmiah Pendidikan MIPA, 7(2), 130-143.

Zakiyah, S., Imania, S. H., Rahayu, G., \& Hidayat, W. (2018). Analisis kemampuan pemecahan masalah dan penalaran matematik serta SelfEfficacy siswa SMA. JPMI (Jurnal Pembelajaran Matematika Inovatif), 1(4), 647-656. https://doi.org/10.22460/jpmi.v1i4.p647-656 
